\title{
Youth Perceptions of Sex Education at The University of Muhammadiyah Jakarta
}

${ }^{1}$ Erlangga Putera Pamungkas, ${ }^{2}$ Gema Ariyanda, ${ }^{3}$ Muchafit Kurniawan, ${ }^{4}$ Sahid hawa

Faculty of Public Health, Muhammadiyah University of Jakarta

K.H. Ahmad Dahlan St, Cireundeu, Ciputat, South Tangerang, 15419

E-mail: putraangga1000@gmail.com

\begin{abstract}
Adolescence is a period of transition from childhood to adulthood during which one undergoes psychological, cognitive, and sexual changes. Indonesian youth still lack knowledge about sexuality and reproductive health, because it is still considered taboo to convey information about it. This study aims to determine the perception of adolescents about sex education at the University of Muhammadiyah Jakarta. The factors studied were knowledge and perception. This research activity was carried out in June-July 2021. This research is qualitative research and the main informants of this research are 4 students of the Faculty of Public Health, University of Muhammadiyah Jakarta, who are not married, with 2 people each from semester 4 and semester 6. The research used a phenomenological qualitative method with data analysis based on content analysis and synthesis tables. Validation of this research data using triangulation of sources and observation of secondary data. Although the informants considered there was a controversy that sex education could protect negative things, it could also increase children's curiosity towards negative things. However, all informants considered sex education very important. Informants still view the goals of sex education as normative, according to the perception of adolescent students from the Faculty of the Public Health University of Muhammadiyah Jakarta, that the current environment directs people or teenagers to have free sex.
\end{abstract}

Keywords: Adolescence, Perception, Education, Sex 


\section{INTRODUCTION}

Adolescence is a period of transition from childhood to adulthood that undergoes psychological, cognitive, and sexual changes. Adolescence is divided into early adolescence aged 1013 years, middle adolescence aged 14-16 years, late adolescence aged 17-19 years (WHO, 2014). According to the World Health Organization (WHO), adolescents are individuals who are undergoing a transition that gradually reaches sexual maturation, undergoes sexual changes, experiences mental changes, from children to adults, a state of dependence to become relatively independent. During the transition to adulthood, adolescents often encounter adolescent sexual problems which will certainly have an impact on their lives. This is due to the lack of knowledge of today's youth about sex education (Notoatmodjo,2002).

Indonesian youth still lack knowledge about sexuality and reproductive health, because it is still considered taboo to convey information about it. In addition, more than $80 \%$ of teens feel more comfortable discussing sexual issues with their friends. So the information they receive may be still unclear, even though if it is known the risks and impacts of having premarital sex, these numbers should be reduced (Fadli, 2007).

Sex education or education on reproductive health or sex education should be given to children who are growing up or teenagers, either through formal or non-formal education. According to (Sarwono, 2011), sex education is one way to reduce or prevent sexual abuse. Especially to prevent unwanted negative effects such as unplanned pregnancy, sexually transmitted diseases, depression, and feelings of guilt.

According to the Indonesian Demographic and Health Survey (IDHS) in 2012, compared to the 2002 and 2007 IDHS, there was an increase in adolescent premarital sex. The survey, which uses secondary data from the 2012 IDHS on adolescent reproductive health, was conducted on unmarried girls and boys. As a result, $8.3 \%$ of boys and $1 \%$ of girls had premarital sex. Most sexual intercourse was carried out in adolescents aged 20-24 years by $9.9 \%$ and at the age of 15-19 years as much as $2.7 \%$.

A survey conducted by the National Youth Risk Behavior Survey (YRBS) in the United States in 2006 found that $47.8 \%$ of students in grades $9-12$ had had premarital sex, 35\% of high school students were sexually active. A survey conducted by Indonesian National Commission for Child Protection in collaboration with Child Protection Institutions in 12 major cities in 2012 found that $62.7 \%$ of junior high school youth admitted that they were no longer virgins. BKKBN data also shows that every year there are at least 2.4 cases committed by teenagers.

\section{METHODS}

This research is a type of qualitative research by conducting in-depth interviews using a questionnaire that asks 25 questions about perceptions of sex and sex education to each of 2 student 
informants from the Faculty of Public Health, Muhammadiyah University, Jakarta semester 4 and 6 in-person and online.

\section{RESULTS AND DISCUSSIONS}

The definition of sex according to female students at UMJ with an Islamic environment, there is one informant who considers sex taboo to talk about, then another opinion that sex is seen as a biological need, a way of reproduction, and a gender distinction.

Table 1. Interview Matrix

\begin{tabular}{|c|c|c|c|c|c|c|}
\hline Topic & & Meaning unit & Code & Subcategory & Category & Theme \\
\hline $\begin{array}{l}\text { What is } \\
\text { difference } \\
\text { between } \\
\text { and } \\
\text { education? }\end{array}$ & $\begin{array}{l}\text { the } \\
\text { sex } \\
\text { sex }\end{array}$ & $\begin{array}{l}\text { 1. If sex is } \\
\text { behavior, what } \\
\text { is sex } \\
\text { education } \\
\text { about science } \\
\text { that studies } \\
\text { sex? } \\
\text { 2. Sex is the } \\
\text { thing that } \\
\text { distinguishes } \\
\text { gender } \\
\text { between men } \\
\text { and women, } \\
\text { for sex } \\
\text { education in } \\
\text { my opinion is } \\
\text { education to } \\
\text { study sex } \\
\text { education to } \\
\text { other people. } \\
\text { 3. Sex is related } \\
\text { to physiology } \\
\text { if the } \\
\text { education is so } \\
\text { that we avoid } \\
\text { sexual } \\
\text { diseases } \\
\text { 4. } \\
\text { education Sex } \\
\text { teaches people } \\
\text { how to stay } \\
\text { away from } \\
\text { negative } \\
\text { behavior }\end{array}$ & $\begin{array}{l}\text { 1. Sex is } \\
\text { behavior } \\
\text { and sex } \\
\text { education is } \\
\text { the study of } \\
\text { sex } \\
\text { 2. Sex as } \\
\text { genitals, and } \\
\text { sex } \\
\text { education to } \\
\text { study sex } \\
\text { 3. Sex } \\
\text { related to } \\
\text { physiology } \\
\text { and } \\
\text { education to } \\
\text { avoid bad } \\
\text { effects } \\
\text { 4. Education is } \\
\text { a way of } \\
\text { teaching } \\
\text { people } \\
\text { about sexual } \\
\text { behavior }\end{array}$ & $\begin{array}{l}\text { Differences in } \\
\text { perception }\end{array}$ & Sex education & Sex education \\
\hline
\end{tabular}

Both informants who have a background in semester 4 and semester 6 view that the purpose of sex education is normative, namely first to avoid sexual behavior before marriage. Second, avoiding the negative impacts and losses resulting from sex outside of marriage. These students have different semesters but have the same perspective or perception about the purpose of sex education. 
Although the informants considered there was a controversy that sex education could protect negative things, it could also increase children's curiosity towards negative things. However, all informants considered sex education very important.

\section{CONCLUSIONS AND SUGGESTIONS}

Sex education is a conscious effort to prepare and form adult human beings who can lead a happy life, can use their sexual function, and are responsible both from an individual, social and religious perspective.

Both informants who have a background in semester 4 and semester 6 view that the purpose of sex education is normative, namely first to avoid sexual behavior before marriage. Second, avoiding the negative impacts and losses resulting from sex outside of marriage. These students have different semesters but have the same perspective or perception about the purpose of sex education.

According to the perception of adolescent students from FKM UMJ, it was conveyed that the current environment directs people or teenagers to have free sex. Students still maintain the perception that sex education aims to avoid sex outside of marriage and prevent it from being negative impacts.

One of the parties who play an important role in sex education is parents. This is due to the intimate and intimate relationship between the child and the parent. The issue of sex is a personal matter which will certainly be much better when it is conveyed by someone who has a very close relationship with the child.

Educational institutions and health services are advised to be able to provide education with the latest methods to attract the attention of adolescents and children from an early age to increase knowledge about sex education and handle sexual behavior in a good way.

\section{REFERENCES}

Bungin, B. (2001) Erotika Media Massa. Surakarta: Universitas Muhammadiyah Surakarta. Darajat, Z. (1977) Membina Nilai-Nilai Moral di Indonesia. Jakarta: Penerbit Bulan Bintang. Dariyo, A. (2004) Psikologi Perkembangan Remaja. Bogor: Ghalia Indonesia.

Djiwandono, S. E. W. (2008) Pendidikan Seks Keluarga. Jakarta: PT Indeks.

Fadli, A. (2007) Peilaku Seks Bebas Pada Remaja di Kecamatan Wajo Makassar.

Hasbullah (2005) Dasar-Dasar Ilmu Pendidikan. Jakarta: raja Grafindo Persada.

Kartono, K. (2001) Bimbingan Belajar. Jakarta: Rajawali.

M, E., Setiadi and Kolip, U. (2013) Pengantar Sosiologi; Pemahaman Fakta dan Gejala Permasalahan Sosial: Teori, Aplikasi dan Permasalahannya. Jakarta.

Moleong, L. J. (2006) Metodologi Penelitian Kualitaif. Bandung: PT. Remaja.

Monks, F. J. and Knoers, A. M. P. (2006) Psikologi Perkembangan. Yogyakarta: Gajah Mada University. 
Mubin, M. and Asrori, A. M. (1998) Menyikapi Problem Seks Suami Isteri. Surabaya: Al Miftah.

Mulyono, B. (1993) Mengatasi Kenakalan Remaja. Yogyakarta: Yayasan Andi.

Notoatmodjo, S. (2002) Metodelogi Penelitian Kesehatan. Revisi. Jakarta: Rineka Cipta.

Rakhmat, J. (2007) Psikologi Komunikasi. Bandung: PT Remaja Rosdakarya.

Rasyid, M. (no date) Pendidikan Seks, Mengubah Seks Abnormal Menuju Seks yang Lebih Bermoral.

Sa'abah, M. U. (2001) Perilaku Seks Menyimpang dan Seksualitas Kontemporer Umat Islam. Yogyakarta: UII Press.

Sarwono, S. W. (2012) Psikologi Remaja. Jakarta: PT Raja Grafindo Persada.

Sarwono, S. W. and Amisiamsidar (1986) Peranan Orang Tua dalam Pendidikan Seks. Jakarta: Rajawali.

Sarwono, W. (2011) Psikologi Remaja. Jakarta: Rajawali Pres.

Slameto (1995) Belajar dan Faktor-Faktor yang Mempengaruhinya. Jakarta: PT Rineka Cipta.

Soekanto, S. (2004) Sosiologi Keluarga Tentang Ikhwal Keluarga, Remaja dan Anak. Jakarta: Rineka Cipta.

Surtiretna, N. (2001) Bimbingan Seks bagi Remaja. Bandung: Remaja Rosda Karya.

Sutopo, H. . (2002) Metodologi Penelitian Kualitatif. Surakarta: Sebelas Maret University Press.

Thoha, C. (1996) Kapita Selakta Pendidikan Islam. Yogyakarta: Pustaka Pelajar.

Ulwan, A. N. and Hathout, H. (1992) Pendidikan Anak Menurut Islam Pendidikan Seks. Bandung: PT Remaja Rosdakarya.

Walgito, B. (2010) Pengantar Psikologi Umum. Yogyakarta: Andi. 
Volume I Tahun 2021

November 2021
E-ISSN: 2808-5361

http://e-journal.fkmumj.ac.id/
Proceeding The First Muhammadiyah InternasionalPublic Health and Medicine Conference 